\title{
PHYTOCHEMICAL SCREENING OF HONEY PINEAPPLE PEEL EXTRACT AND ITS APPLICATION AS AN ANTIBACTERIAL ADDITIVE IN DISH SOAP FORMULATION
}

\section{Elfi Susanti VH ${ }^{1^{\star}}$, Sri Mulyani ${ }^{1}$, Sri Retno Dwi Ariani ${ }^{1}$, Suryadi Budi Utomo', and Bayu Antrakusuma ${ }^{2}$}

\author{
${ }^{1}$ Chemistry Education Study Program, Faculty of Teacher Training and Education, \\ Universitas Sebelas Maret,
} Jl. Ir. Sutami No. 36A, Surakarta, Central Java 57126, Indonesia

\author{
${ }^{2}$ Science Education Study Program, Faculty of Teacher Training and Education, \\ Universitas Sebelas Maret, \\ Jl. Ir. Sutami No. 36A, Surakarta, Central Java 57126, Indonesia \\ * Correspondence: Email: elfisusantivh@staff.uns.ac.id
}

\begin{abstract}
This research aims to scientifically develop bioactive compounds from honey pineapple peel and develop a dish soap formulation with extract additives of honey pineapple peel that can be antibacterial. The research was conducted in stages, namely process of extracting honey pineapple peel was carried out by the maceration method using $96 \%$ ethanol as a solvent, phytochemical screening of the ethanol extract of honey pineapple peel was done to determine the class of compounds contained in the extract, and application of honey pineapple peel extract in dish soap formulation was to obtain a dish soap formulation with optimal antibacterial activity. Testing the ability of dish soap products to inhibit Staphylococcus aureus bacteria was performed by the method of filter paper disc diffusion. The results revealed that the ethanol extract of honey pineapple peel contained alkaloids, flavonoids, tannins, and saponins. The ethanol extract of honey pineapple peel has been applied in a dish soap formulation and tested for the antibacterial activity of $S$. aureus. Antibacterial test results showed that the dish soap formulation with the addition of $5 \%$ pineapple peel extract provided strong antibacterial activity, indicated by a precise zone formation of $12.60 \mathrm{~mm}$.
\end{abstract}

Keywords: honey pineapple peel extract, dish soap, antibacterial, S. aureus

\section{INTRODUCTION}

\section{Pineapple (Ananas comosus (L.)} Merr.) is a type of tropical plant originating from Brazil, Bolivia, and Paraguay. This plant belongs to the Bromeliaceae family. Pineapple is a type of fruit that is high in nutrients. One of the pineapples that are popular in Indonesia is honey pineapple. This type of pineapple has a delicious and refreshing taste. The pulp of honey pineapple has a thicker pulp than pineapples in general, is more extensive than regular pineapples, and has a slightly yellowish color to orange. Pineapple fruit contains lots of nutrients, including vitamin A, calcium, phosphorus, magnesium, iron, sodium, potassium, 
dextrose, sucrose (cane sugar), and the enzyme bromelain, which is a $95 \%$ mixture of cysteine proteases that can hydrolyze protein (proteolysis) and resistant to heat [1].

Apart from the pulp, pineapple peel also brings many benefits. Pineapple pulp contains many nutrients, and pineapple peel is known to have antioxidants helpful in warding off free radicals [2]. Pineapple peel also contains nano cellulose which is helpful in the pharmaceutical, food and medical industries. Nanocellulose from pineapple peel has been used as a tooth-strengthening material [3].

The various activities owned by the pineapple peel are inseparable from its compound content. The content of compounds in each plant can be affected by differences in growing places, such as soil conditions, temperature, light, and climate. In this case, one of the honey pineapple producers in Central Java is the Pemalang area. Nevertheless, honey pineapple peel has not been used optimally. In this study, phytochemical screening aimed to determine the class of compounds in the ethanol extract of honey pineapple peel originating from the Pemalang area, Central Java.

Further, phytochemical screening is a simple, fast, and highly selective method that can be employed to identify classes of compounds and determine the presence of biologically active compounds distributed in plant tissues [4]. Meanwhile, the bacterial infection is a health problem caused by bacteria and can attack all body organs. Bacteria enter the body in many ways, for example, through food or drink contaminated with bacteria, contact with body fluids such as faeces, urine, and blood from people infected with bacteria, and from using eating and drinking utensils [5]. Contaminated food and drink from cutlery are a cause of bacterial infection. Therefore, everyone should use eating and drinking utensils that are clean from bacteria. An effort that can be made to get bacteria-free tableware is to use antibacterial dish soap.

Plant extracts have been widely used in antibacterial liquid soap formulationsantiseptic liquid soap formulation for hand use using celery leaf extract. The chemical content of celery leaf extract has been reported to contain essential oils, flavonoids, coumarin and carbohydrates. The best liquid soap preparation formula is $2.5 \%$ concentration. The antiseptic liquid soap obtained did not change the smell, color, skin $\mathrm{pH}$ ranged from 5.0 to 6.5 , and there was no irritation to the skin of the volunteers [6]. The ethanol extract of basil leaves has been used to formulate hand washing liquid soap [7]. The ethanol extract of basil leaves (Occimum basilicum L.) used in the preparation of $10 \%$ liquid handwashing soap and $2 \%$ carbopol thickener concentration provides liquid hand soap with the most optimal physical stability.

Plant extracts in liquid soap formulation have been carried out using the ethanol extract of the Pacar water flower. The results of testing the quality of liquid soap for water Pacar flower ethanol extract that meet the requirements following the standards set by $\mathrm{SNI}$ are organoleptic test, $\mathrm{pH}$ test, high foam test, moisture content test, free alkaline test and specific gravity test. The test results for the antibacterial effectiveness of liquid soap with the ethanol extract of Pacar water 
flower can inhibit $S$. aureus bacteria, namely, a concentration of $5 \%$, a concentration of $10 \%$ and $15 \%$ in the moderate inhibition zone category [8]. Other research has used teak leaf extract in an antibacterial liquid soap formulation. Teak leaves contain flavonoid compounds and are used as antibacterial agents. Teak leaf extract liquid soap has quality according to SNI standards and has antibacterial activity against $E$. coli and $S$. aureus [9], and lime juice in a handwashing soap formulation. The product obtained is in the form of antiseptic handwashing soap that meets the organoleptic specifications and specific gravity required by the SNI [10].

Apart from being used in liquid hand soap formulations, plant extracts have also been used in antibacterial dishwashing soap formulations. Aloe vera extract has also been used in making dish soap [11]. A product in the form of liquid dish soap that not only cleans the remaining dirt on food utensils but can also act as an antibacterial from the use of aloe vera extract. Based on the study results, it was found that the concentration of $1 \mathrm{ml}$ of aloe vera extract in $250 \mathrm{ml}$ of the sample could inhibit the development of $\mathrm{E}$. Coli bacteria by $20.28 \mathrm{~mm}$; this result is greater than dishwashing soap products on the market. Based on the results of testing and observations of product quality standards that have been carried out, it can be seen that the product is following the SNI quality standard number 06-2048-1990 [11]. The formulation of dish soap with coffee bean extract has also been carried out in the form of dish soap with a coffee aroma and is active as an antibacterial. This liquid has a thick texture, suitable for dishwashing liquids in general [12].

One of the biodiversity that can be developed as an antibacterial is the waste of honey pineapple peel. Several studies have been conducted regarding the antibacterial power test of pineapple extract and testing the inhibition of pineapple extract Salak (Salacca zalacca), and kweni mango (Mangifera odorata) extracts against $S$. aureus bacteria. Showed that the results of pineapple extract could inhibit the growth of S. aureus bacteria with a concentration of $50 \%$ and $100 \%[13]$. Other researchers tested the antibacterial activity of pineapple peel extract with chloroform, acetone, and methanol as solvents[14]. The results disclosed that pineapple peel's chloroform extract had activity against $S$. aureus, Corynebacterium rubrum, Klebsiella pneumonia, and S. typhimurium. However, it did not show any activity against $S$. subflava, Enterobacter aerogenes, and Proteus mirabilis. Pineapple peel acetone extract showed activity against Staphylococcus aureus, S. subflava, Enterobacter aerogenes, Klebsiella pneumonia, Proteus mirabilis, and $S$. typhimurium. The methanol extract showed activity against $S$. aureus and Klebsiella pneumonia, but did not show activity against $S$. subflava, Enterobacter aerogenes, Proteus mirabilis, and $S$. typhimurium. No one has reported honey pineapple peel extract applied as dish soap as an antibacterial against $S$. aureus [14]. The use of pineapple peel extract in dish soap formulation has not been carried out. Therefore an effort to utilize pineapple peel 
waste as an antibacterial agent in dish soap is very important.

\section{METHODS}

\section{Sample Collection and Preparation}

The sample used was the honey pineapple peel, taken from honey pineapple traders from Pemalang, Central Java.

\section{Preparation of Honey Pineapple Fruit Peel Ethanol Extract}

Fresh honey pineapple peel was chopped first and dried at room temperature. The dry sample was extracted using $96 \%$ ethanol solvent for 24 hours. After the substances contained in pineapple peel dissolve in ethanol, it was filtered utilizing a Buchner to get the filtrate. The process was repeated until the pineapple peel content was completely extracted in ethanol. The filtrate was then evaporated in a rotary evaporator at a temperature of $40-50^{\circ} \mathrm{C}$ until a thick extract was obtained.

\section{Phytochemical Screening of Honey Pineapple Peel Ethanol Extract}

Phytochemical tests on the ethanol extract of pineapple peel included examining alkaloids, flavonoids, saponins, tannins, polyphenols, glycosides, steroids, and triterpenoids.

\section{Extraction of honey pineapple peel with ethanol $96 \%$}

The honey pineapple peel was collected about $5 \mathrm{~kg}$, then dried at room temperature and blended to obtain a powder weight of $1 \mathrm{~kg}$. The extraction process by maceration used $96 \%$ ethanol (24 hours). The filtrate was collected, while the residue was extracted again with $96 \%$ ethanol (24 hours). The filtrate was collected again and combined with the first extract. Solvent evaporation utilized a rotary evaporator to obtain rotary results in the form of thick extracts.

\section{Phytochemical screening}

The phytochemical test solution was prepared by dissolving $3 \mathrm{~g}$ of honey pineapple peel's ethanol extract with $30 \mathrm{ml} 96 \%$ ethanol [15]

\section{a. Alkaloid test}

A total of $2 \mathrm{~mL}$ of the test extract solution was evaporated on a porcelain dish until a residue was obtained. The residue was then dissolved with $5 \mathrm{~mL} 2 \mathrm{~N} \mathrm{HCL}$. The solution obtained was then divided into three test tubes. In the first tube, dilute acid was added, which served as a blank. Three drops of Dragendorff reagent were added in the second tube, and in the third tube, three drops of Mayer reagent were added. The formation of orange deposits in the second tube and yellow deposits in the third tube indicates alkaloids.

\section{b. Flavonoid test}

A total of $2 \mathrm{~mL}$ of the test extract solution was heated for about 2 minutes. After heating, then add 4-5 drops of concentrated $\mathrm{HCl}$ and 0.1 gram of $\mathrm{Mg}$ powder. The appearance of yellow-orange indicates positive results to dark red (magenta) within 3 minutes.

\section{c. Phenolic test}

A total of $2 \mathrm{~mL}$ of the test extract solution was added to $1-2$ drops of $1 \%$ iron (III) chloride solution. If a blue or purple color is formed, it indicates a phenolic compound. 


\section{d. Tannin test}

A total of $2 \mathrm{~mL}$ of the test extract solution was added with a few drops of $10 \%$ $\mathrm{FeCl}_{3}$ solution. The tannin test result is positive if the solution changes color to blackish green or blackish blue.

\section{e. Steroid and triterpenoid tests}

A total of $2 \mathrm{~mL}$ of the test extract solution was put in a test tube, then dissolved in $0.5 \mathrm{~mL}$ of chloroform. Then, add $0.5 \mathrm{~mL}$ of glacial acetic acid and add 1-2 mL of concentrated $\mathrm{H} 2 \mathrm{SO} 4$ through the tube wall. The presence of triterpenoids is indicated by a brown or violet ring at the border of the two solvents. Meanwhile, the presence of steroids is indicated by a bluish-green color.

\section{f. Saponin test}

A total of $1 \mathrm{~g}$ of the thick extract was put into a test tube. Then, add warm water. Next, the solution was shaken for 1 minute. If foam arose, it was added with $\mathrm{HCl} 1 \mathrm{~N}$. If the foam formed can last for 5 minutes, the extract is positive for saponins.

\section{g. Glycoside test}

A total of $2 \mathrm{~mL}$ of the test extract solution was evaporated on a water bath. Dissolve the remaining in $5 \mathrm{~mL}$ of concentrated anhydrous acetic acid. Add ten drops of concentrated sulfuric acid.

\section{Preparation of dish soap from honey pineapple peel extract}

Dish soap of pineapple peel extract was made by using variations in the form of extract concentrations. The composition of HEC, Texapon70 and other ingredients was made in the same amount in each formula. The preparation of dish soap began with making solution A with the following steps. Add $2 \mathrm{~g}$ of $\mathrm{HEC}$ and $20 \mathrm{~g}$ of $\mathrm{NaCl}$ in the beaker $1000 \mathrm{ml}$. Add $200 \mathrm{ml}$ of distilled water, stir until evenly distributed, and add $125 \mathrm{~g}$ of Texapon 70. Stir again and add $20 \mathrm{ml}$ of Terpitol NPX.

Meanwhile, solution $B$ was made by adding $2 \mathrm{~g}$ of sodium benzoate and $2 \mathrm{~g}$ of citric acid into a $1000 \mathrm{ml}$ beaker. Then, add $650 \mathrm{ml}$ of distilled water and stir until evenly distributed. After that, add the pineapple peel extract according to the formulation and stir again until evenly distributed. Mix solution A and solution $B$ into a stainless pan and heat it over low heat to produce dish soap.

\section{Antibacterial activity testing}

Antibacterial test of dish soap from honey pineapple peel extract employed the disc diffusion method. The procedures carried out referred [16]. It started by dipping a sterile cotton swab in a bacterial suspension equal to McFarland's turbidity and waiting for it to soak into the cotton. Then, apply the cotton stick to the Mueller Hinton Agar (MHA) medium until smooth. Take a blank disc paper with a diameter of $6 \mathrm{~mm}$ that has been pre-sterilized in an oven at $121^{\circ} \mathrm{C}$ for 15 minutes and place it on the surface of the agar medium. Drop sterile aqua using a 20 microliter micropipette as a negative control and do the same for chloramphenicol as a positive control. Then, take a blank disc paper and place it on the surface of the media. Afterwards, drip preparation 1 using a 20-microliter micropipette and do the same for preparation 2, preparation 3 , and control. After that, incubate in an incubator for $1 \times 24$ hours at $37^{\circ} \mathrm{C}$. Then, measure the bacterial inhibition zone formed with a calliper [16]. 
RESULTS AND DISCUSSION

\section{The Process of Taking Honey Pineapple Peel Extract}

Honey pineapple skins are taken from a seller in the Surakarta area. The dried pineapple peel powder $(1 \mathrm{~kg})$ was extracted by maceration for 24 hours, and after the evaporation process, a concentrated dark extract $(74 \mathrm{~mL}$ ) was obtained (Yield $7.4 \%)$. This concentrated extract is used for phytochemical screening and dish soap formulations.

\section{Phytochemical Screening}

Phytochemical screening is one way to identify the content of secondary metabolites of natural substances. At this stage, it can provide an overview of the content of active compounds in the natural ingredients studied.

The active ingredients in a plant serve as self-defence plants against the environment, disease and attack by predators.

Phytochemical screening of the honey pineapple peel's ethanol extract was carried out to determine the class of compounds in the extract, as shown in Table 1. The results show that ethanol extract contains alkaloids, flavonoids, tannin and saponin.

Alkaloids are polar compounds, so they are attracted to ethanol solvents. Flavonoids have bonds with sugar groups that cause flavonoids to dissolve more easily in water or polar solvents. Tannins are phenolic compounds that tend to dissolve in water and are polar solvents, while saponins are triterpene glycosides that tend to be polar [15].

These results are the same as [17] previous research, which states that the pineapple peel extract positively contains flavonoids, alkaloids, tannins, and saponins, phenolic compounds, steroids, and triterpenoids.

\section{Dish soap formulation}

The formulation of dish soap was carried out to obtain dishwashing soap with properties following the standard dish soap that has been widely used in society. From the three formulations, it was found that the resulting dish soap was less viscous in formulation $\mathrm{A}$. In formulation $\mathrm{B}$, the resulting dish soap was not too thick or runny, while in formula $\mathrm{C}$, the soap was too thick. Thus, the appropriate formulation was obtained, namely, dish soap with formulation B with honey pineapple peel extract into the dish soap formulation, as shown in Table 2 and 3.

\section{Antibacterial Activity Test}

Antibacterial are substances that can inhibit growth or kill bacteria. In the pharmaceutical field, antibacterials are known as antibiotics, which are chemical substances produced by microorganisms that can inhibit growth or kill other microorganisms [5].

An antibacterial test was conducted to determine its potential as antibacterial. Antibacterial activity test was carried out in vitro using the filter paper disc diffusion method. Bacterial growth can be observed after incubation for 24 hours at $37^{\circ} \mathrm{C}$, by looking at the presence or absence of inhibitory area around the filter paper.

Measurement of antibacterial activity was determined against $S$. aureus. The measurement results can be seen in Figure 1 and Table 4. DMSO was used as a negative control for antibacterial activity testing. DMSO does not have antibacterial activity 
because it does not have a clear zone on the disc, so it can be ascertained that the resulting inhibition zone is purely from the test compound and is not influenced by solvents.

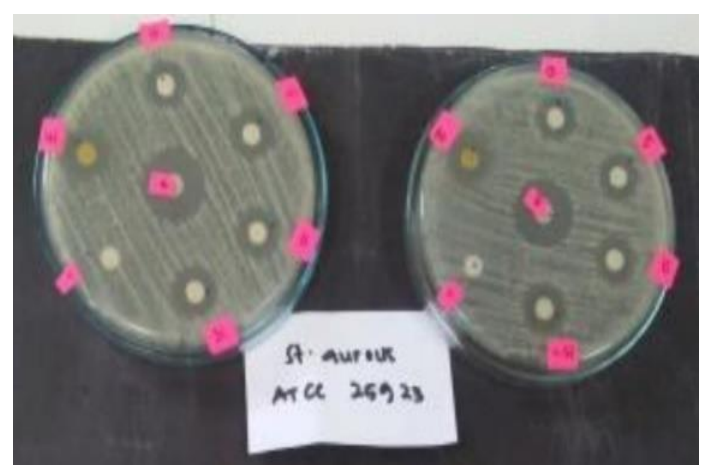

Figure 1. The results of the test sample inhibition against $S$. aureus bacteria

The criteria for the strength of the antibacterial power are based on the diameter of the inhibition zone resulting from the test results[18]. The inhibition zone diameter of 5 $\mathrm{mm}$ or less is categorized as weak. The inhibition zone of $5-10 \mathrm{~mm}$ is categorized as moderate. The inhibition zone of $10-20 \mathrm{~mm}$ is categorized as strong, and the zone of $20 \mathrm{~mm}$ or more is categorized as very strong. Based on these criteria, the antibacterial activity of the ethanol extract of honey pineapple peel
$12.7 \mathrm{~mm}$ is categorized as having strong antibacterial activity [18].

The test results presented in Table 4 display that dish soap formulation I (with $5 \mathrm{~mL}$ extract) showed the best antibacterial activity among the other three formulations. It could be seen from the test results, which revealed a strong inhibitory power of $12.62 \mathrm{~mm}$. Formulation II exhibited the least inhibition. The dish soap's ability with the additive of honey pineapple peel ethanol extract as antibacterial was assumed because the screening results showed that pineapple peel extract contains flavonoids, saponins, and tannins. Many studies have shown that flavonoids are active as antibacterial. Flavonoids could kill bacteria by lysing the bacterial cell wall and reducing bacterial cells' density [19]. Flavonoids work as anti-bacterials with several action mechanisms, including inhibiting nucleic acid synthesis, cytoplasmic membrane function, and energy metabolism from bacteria. Saponins can damage the bacterial cell membranes' integrity [20], whereas tannins inhibit bacterial cell wall synthesis by forming irreversible complex bonds with prolene protein [21].

Table 1. Phytochemical Screening Results of Honey Pineapple Peel Ethanol Extract

\begin{tabular}{|c|c|c|c|c|}
\hline No. & $\begin{array}{l}\text { Phytochemical } \\
\text { Test }\end{array}$ & References & Results & Conclusion \\
\hline 1. & Alkaloid test & $\begin{array}{l}\text { The orange } \\
\text { formed } \\
\text { reagent). }\end{array}$ & $\begin{array}{l}\text { Orange sediment was formed } \\
\text { (Dragendorff reagent). }\end{array}$ & $(+)$ \\
\hline 2. & Flavonoid test & $\begin{array}{l}\text { A yellow precipitate is formed } \\
\text { (Mayer reagent). }\end{array}$ & $\begin{array}{l}\text { A yellow precipitate was } \\
\text { formed (Mayer reagent). }\end{array}$ & $(+)$ \\
\hline 3. & Phenolic test & $\begin{array}{l}\text { Yellow-orange to dark red } \\
\text { color appears. }\end{array}$ & $\begin{array}{l}\text { The brownish-yellow color } \\
\text { appeared. }\end{array}$ & $(-)$ \\
\hline 4. & Tannin test & Blue or purple is formed. & Yellow was formed. & $(+)$ \\
\hline 5. & $\begin{array}{l}\text { Steroid and } \\
\text { triterpenoid } \\
\text { tests }\end{array}$ & $\begin{array}{l}\text { Blackish green or blackish } \\
\text { blue is formed. }\end{array}$ & Dark green or blackish brown & $(-)$ \\
\hline 6. & Saponin test & $\begin{array}{l}\text { A brownish ring is formed on } \\
\text { the border of two solvents and } \\
\text { a bluish-green color. }\end{array}$ & Brownish black & $(+)$ \\
\hline 7. & Glycoside test & Foam is formed. & The foam was formed. & $(-)$ \\
\hline
\end{tabular}


Table 2. Formulations of Dish Soap

\begin{tabular}{clccc}
\hline No & Ingredients & Formulation A & Formulation B & Formulation C \\
\hline 1 & honey pineapple peel ethanol & 0 & 0 & 0 \\
& extract & & & \\
2 & HEC (Hydroxy Ethyl Cellulosa) & $2 \mathrm{gram}$ & $2 \mathrm{gram}$ & $2 \mathrm{gram}$ \\
3 & Texapon 70 & $125 \mathrm{gram}$ & $125 \mathrm{gram}$ & $125 \mathrm{gram}$ \\
4 & NaCl & $20 \mathrm{gram}$ & $20 \mathrm{gram}$ & $20 \mathrm{gram}$ \\
5 & Tergitol NPX & $20 \mathrm{ml}$ & $20 \mathrm{ml}$ & $20 \mathrm{ml}$ \\
6 & Sodium sitric & $2 \mathrm{gram}$ & $2 \mathrm{gram}$ & $2 \mathrm{gram}$ \\
7 & Sitric acid & $2 \mathrm{gram}$ & $2 \mathrm{gram}$ & $2 \mathrm{gram}$ \\
8 & Aquadest & $1000 \mathrm{ml}$ & $600 \mathrm{ml}$ & $500 \mathrm{ml}$ \\
\hline
\end{tabular}

Table 3. Formulation of Dish Soap with The Addition of Honey Pineapple Peel Extract

\begin{tabular}{clcccc}
\hline No & Ingredients & control & Formulation I & Formulation II & Formulation III \\
\hline 1 & $\begin{array}{l}\text { honey pineapple peel } \\
\text { ethanol extract }\end{array}$ & 0 & $5 \mathrm{~mL}$ & $10 \mathrm{~mL}$ & $15 \mathrm{~mL}$ \\
& HEC (Hydroxy Ethyl & $2 \mathrm{gram}$ & $2 \mathrm{gram}$ & $2 \mathrm{gram}$ & $2 \mathrm{gram}$ \\
2 & Cellulosa) & $125 \mathrm{gram}$ & $125 \mathrm{gram}$ & $125 \mathrm{gram}$ & $125 \mathrm{gram}$ \\
3 & Texapon 70 & $20 \mathrm{gram}$ & $20 \mathrm{gram}$ & $20 \mathrm{gram}$ & $20 \mathrm{gram}$ \\
4 & NaCl & $20 \mathrm{ml}$ & $20 \mathrm{ml}$ & $20 \mathrm{ml}$ & $20 \mathrm{ml}$ \\
5 & Tergitol NPX & $2 \mathrm{gram}$ & $2 \mathrm{gram}$ & $2 \mathrm{gram}$ & $2 \mathrm{gram}$ \\
6 & Sodium sitrat & $2 \mathrm{gram}$ & $2 \mathrm{gram}$ & $2 \mathrm{gram}$ & $2 \mathrm{gram}$ \\
7 & Asam sitrat & $600 \mathrm{ml}$ & $600 \mathrm{ml}$ & $600 \mathrm{ml}$ & $600 \mathrm{ml}$ \\
8 & Aquadest & & &
\end{tabular}

Table 4. Antibacterial Test Results of Dish Soap with Honey Pineapple Peel's Extract Additives Against $S$. aureus

\begin{tabular}{lccc}
\hline Sample & Inhibition zone diameter $(\mathrm{mm})$ & average $(\mathrm{mm})$ \\
\hline honey pineapple peel ethanol extract & 12,69 & 12,72 & 12,705 \\
Sabun tanpa ekstrak & 11,91 & 11,52 & 11,715 \\
Formulation I & 12,62 & 12,61 & 12,615 \\
Formulation II & 11,22 & 11,79 & 11,505 \\
Formulation III & 12,13 & 11,99 & 12,06 \\
Vancomycin (positif control) & 20,64 & 20,78 & 20,71 \\
DMSO ( negatif control) & 0 & 0 & 00 \\
\hline
\end{tabular}

\section{CONCLUSION}

Phytochemical screening results of the honey pineapple peel's ethanol extract showed alkaloids, flavonoids, tannins, and saponins. The results also show that it has succeeded in making a dish soap formulation with the additive of honey pineapple peel extract. The product is dish soap which has strong antibacterial activity against $S$. aureus.

\section{ACKNOWLEDGEMENT}

The authors are thankful to Head of LPPM UNS and Dean of FKIP UNS, for funding assistance so that this research can be carried out Wells.

\section{REFERENCES}

[1] L. Erukainure, J. A. Ajiboye, R. O. Adejobi, O. Y. Okafor, \& S. O. Adenekan, "Protective effect of 
pineapple (ananas comosus) peel extract on alcohol induced oxidative stress in brain tissues of male albino rats," Asian Pac. J. Trop. Disease. vol.1, no. 1, pp. 5-9, 2011. doi: 10.1016/S2222-1808(11)60002-9

[2] S. F. Hatam, E. Suryanto, \& J. Abidjulu, "Aktivitas antioksidan dari ekstrak kulit nanas (Ananas comosus (L) Merr)". Pharmacon, vol. 2, no. 1, 2013. doi: 10.35799/pha.2.2013.880

[3] A Evelyna, N. Prakusya, D.J.D. Ariswari, \& B. S. Purwasasmita, "Sintesis dan Karakterisasi Nanoselulosa Berbahan Serat Nanas sebagai Komponen Penguat Material Kedokteran Gigi" Jurnal Material Kedokteran Gigi, vol. 8, no. 2, pp. 6064. 2019.

doi: 10.32793/jmkg.v8i2.453

[4] Nohong. "Skrining Fitokimia Tumbuhan Ophiopogon jaburan Lodd dari Kabupaten Kolaka Provinsi Sulawesi Tenggara," Jurnal Pembelajaran Sains. vol. 5, no. 2, pp. 172-178, 2009.

[5] T. Elliot, T. Worthington, H. Osman, \& M. Gill, "Mikrobiologi Kedokteran dan Infeksi", Penerjemah Natalia Puspadewi, Penerbit Buku Kedokteran EGC: Jakarta, 2009.

ISBN: 978-1-118-37228-9

[6] A .Ardina, \& S. Suprianto, "Formulasi Sabun Cair Antiseptik Ekstrak Etanol Daun Seledri ( Apium graviolens L.)," Jurnal Dunia Farmasi, vol. 2, no.1, pp. 21-28, 2017.

doi: $10.33085 / j d f . v 2 i 1.4393$

[7] N. Nurlina, F. Attamimi, R. Rosvina, \& M. I. Tomagola, ,Formulasi Sabun Cair Pencuci Tangan Yang Mengandung Ekstrak Daun Kemangi (Occimum basilicum L.)," As-Syifaa Jurnal Farmasi, vol . 05. no. 2, pp. 119127, 2013.
[8] S. A. Dimpudus, " Formulasi sediaan sabun cair antiseptik ekstrak etanol bunga pacar air (Impatiens balsamina L.) dan uji efektivitasnya terhadap bakteri Staphylococcus aureus secara In Vitro". Pharmacon, vol.6, no.3, 2017 doi: 10.35799/pha.6.2017.16885

[9] A. J. Chastelyna, S. Supartono, \& N. Wijayati, "Uji Aktivitas Antibakteri Sabun Cair Ekstrak Daun Jati (Tectona Grandis Lf)". Indonesian Journal of Chemical Science, vol.6, no.1, pp.7276.2017.

[10] N. I. E. Jayani, Kartini, \& N. Basirah, "Formulasi Sediaan Sabun Cuci Tangan Ekstrak Jeruk Nipis (Citrus aurantifolia) dan Efektivitasnya sebagai Antiseptik," MPI (Media Pharmaceutica Indonesiana), vol.1, no. 4, pp. 222-229, 2018.

doi:10.24123/mpi.v1i4.887

[11] M. Rahardjo, E. B. Koendhori, \& Y. Setiawati, "Uji aktivitas antibakteri ekstrak etanol lidah buaya (Aloe vera) terhadap bakteri Staphylococcus aureus". Jurnal Kedokteran Syiah Kuala, vol. 17, no.2, pp. 65-70,2017. doi:10.24815/jks.v17i2.8975

[12] A. Sridevi, \& N. Deswita, "Formulasi Sabun Cuci Piring Dengan Ekstrak Bubuk Kopi", Proceeding of 4 th International Conference on Education September 25-26, 2019,

[13] E. Suerni, M. Alwi, \& M. M. Guli, "Uji Daya Hambat Ekstrak Buah Nanas (Ananas comosus L. Merr.), Salak (Salacca edulis Reinw.) dan Mangga Kweni (Mangifera odorata Griff.) terhadap Daya Hambat Staphylococcus aureus". Biocelebes, vol. 7 , no. 1,2013 .

[14] S. Chanda, Y. Baravalia, Y. Kaneria, \& K. Rakholia, "Current Research Technology and Education Topic in Applied Microbiology and Microbial 
Biotechnology". A. Mendez-Vilas (Ed). pp 444-450, 2010. ISBN:9788461461943

[15] J. B. Harbone, "Metode Fitokimia: Penuntun Cara Modern Menganalisis Tumbuhan," Edisi Kedua. Bandung : Penerbit ITB. pp 4-147, 2006.

ISBN:9798001141

[16] M. Balouiri , M. Sadiki, \& S. K. Ibnsouda, "Methods for in vitro evaluating antimicrobial activity," A review. Journal of Pharmaceutical Analysis, vol.6, no.1, pp. 71-79, 2016. doi:10.1016/j.jpha.2015.11.005

[17] I. A. Reiza, L. Rijai, \& F. Mahmudah, "Skrining Fitokimia Ekstrak Etanol Kulit Nanas (Ananas comosus (L.) Merr)", Proc. Mul. Pharm. Conf., vol. 10, no. 1, pp. 104-108, Oct. 2019.

doi:10.25026/mpc.v10i1.371

[18] W. W. Davis, \& T. R. Stout, "Disc Plate Methods of Microbiological Antibiotic Assay," Microbiology. 22(4): 659-665, 1971.
[19] J. Dzoyem, S. Guru , C Pieme , V. Kuete, A. Sharma, \& I. Khan, "Cytotoxic and antimicrobial activity of selected Cameroonian edible plants," BMC Complement Altern Med. vol. 13, no. 1, pp.78, 2013.

doi:10.1186/1472-6882-13-78

[20] P. Xue, Y. Yao, X. S. Yang, J. Feng, \& G. X. Ren, "Improved antimicrobial effect of ginseng extract by heat transformation," Journal of Ginseng Research, vol. 41, no. 2, pp. 180-187, 2017.

doi:10.1016/j.jgr.2016.03.002

[21] B. Mamtha, K. Kavitha, K. K., Srinivasan, \& P. G. Shivananda, "An in vitro study of the effect of Cantella asiatica (Indian pennywort) on enteric pathogens," Indian Journal of Pharmacology, vol. 36, no. 1, pp. 41, 2004. 